\title{
Phytochemical Screening, Cytotoxicity, Antioxidant and Antimicrobial Activities of Stem and Leave Extracts of Euphorbia Heterophylla.
}

Okeniyi, S.O. (Corresponding author)

Department of Chemistry

Nigerian Defence Academy, Kaduna

E-mail: drokeniyisok@yahoo.com

Adedoyin, B. J

Department of Chemistry

Nigerian Defence Academy, Kaduna

Garba, S

Department of Chemistry

Nigerian Defence Academy, Kaduna

Received: July 5, 2012 Accepted: July 18, 2012

doi:10.5296/jbls.v4i1.2047～URL: http://dx.doi.org/10.5296/jbls.v4i1.2047

\begin{abstract}
Phytochemical screening carried out on the stem and leave extracts of Euphorbia heterophylla (Euphorbieacea) confirmed the presence of Carbohydrates, gycosides, reducing sugar, saponins, taninns, phlobatanins, cardiac glycosides, steroids, triterpenes, and flavonoid. cytotoxicity test using brine shrimp lethality assay gave the $\mathrm{LC}_{50}$ value $\left(\mu \mathrm{g} / \mathrm{cm}^{3}\right)$ are 20.67 , 25.07, 158.56, and 176.55 for n-Hexane fraction, Ethyl Acetate fraction, Butanol fraction and Aqueous fraction of the stem while $23.50,30.20,164.10$ and 179.80 for n-hexane fraction, Ethyl Acetate fraction, Butanol fraction and Aqueous fraction of the leave extracts. The results of antioxidant properties of the stem and leaves extracts showed that the extracts exhibited strong activity as a radical scavenger in the experiment using 2, 2-diphenyl-1-picryhydrazyl radical (DPPH) indicating that the plant has strong ability to
\end{abstract}


donate hydrogen when compared with the standard butyrate hydroxyl anisole (BHA). The antimicrobial activity of the extracts was carried out against Staphylococcus aureus, E.coli, Pseudomonas aeruginosa, Streptococcus pneumonia, and Candida albicans, the results showed moderate to low activity for the test organisms.

Keywords: Phytochemical screening, Antimicrobial activity, Antioxidant activity, Euphorbia heterophylla.

\section{Introduction}

Plants or herbs have been found to have medicinal and therapeutic importance in the prevention, treatment or cure of diseases and ailment. This knowledge has been passed down from one generation to another either verbally or in writing (Sofowora, 2008).The universal role of plants in the treatment of diseases is exemplified by their employment in all major systems of medicine (Okeniyi et al., 2007). Euphorbia heterophylla is a toxic plant which belongs to the family of Euphorbiaceae. It is commonly called Mexican fire plant, milk weed and Spurge weed in English. The toxicity of the plant, especially the root and latex is recognized in Africa. The latex is acrid and the toxic principle is neither alkaloid nor glycoside but probably a resin which can prove fatal (Hartwell et al., 1969). Despite the toxicity hazard of this plant, it has various medicinal properties which include its use in the reatment of gonorrheal, respiratory tract infection, malaria, eczema, asthma and wart cure.

The report by Omale and Emmanuel, (2010) shows that the Ethanol extract and water free extract of Euphorbia heterophylla leave contain some wound healing properties. (Falodun and Agbakwuru, 2004) reported the isolation of a flovonoid, quercetin from crude extract of the leaves of this plant. The leave is known to posse's antibacterial activity (Falodun et al 2003). Toxicity is documented in most of the genus Euphorbia with individual sensitive to latex. This study investigated the antioxidant, cytotoxicity, and antimicrobial activity of stem and leave extracts of Euphorbia heterophylla plant.

\section{Materials and Methods}

Plant Collection and Identification; The stem and the leave of Euphorbia heterophylla. Was collected from Nigerian defence academy Afaka area Kadunna, the sample was identified by Mr Yahaya Abdullahi of Herbarium section, Biological Science Department, Nigerian Defence Academy. The collected leave and stem were cleaned, air dried and pulverized.

Extraction; A portion (200 g) each of the pulverized plant material were separately extracted using soxhlet apparatus with $\left(500 \mathrm{~cm}^{3}\right)$ methanol each as solvent. The extracts was collected and concentrated with the aid of a rotary evaporator at $40^{\circ} \mathrm{C}$ to obtain the crude extracts which was weighed and kept at ambient temperature.

Fractionation:

A portion $(21 \mathrm{~g})$ of crude extract was dissolved in $250 \mathrm{~cm}^{3}$ distilled water in a separatory funnel and $250 \mathrm{~cm}^{3}$ of $\mathrm{n}$-hexane were added, shaken and allow to stand over night for the two layers to 
separate. The two layers were drain separately and the upper n-hexane layer was evaporated using rotary evaporator, The same procedure was repeated using - Ethyl acetate $\left(250 \mathrm{~cm}^{3}\right)$ and Butanol $\left(250 \mathrm{~cm}^{3}\right)$ to get Hexane, Ethyl acetate and Butanol fraction. (Aliyu et al 2008).

Phytochemecal Screening; The crude extracts above was used to test for the presence of the following secondary metabolites: alkaloids, flavonoids, steroids, saponins, phenols, tannins, glycosides, reducing sugars, anthrquinones, carbohydrates, resin, cardiac glycosides, and tannins, using standard methods described by Okeniyi et al., (2007) and sofowora ( 2008).

Brine Shrimp Cytotoxicity Test; screening of the extracts against Brine shrimp larvae was carried out according to Falope et al (1993) and Oloyede et al (2010). In this assay, a drop of dimethyl sulphoxide (DMSO) was added to test and control vials to enhance the solubility of the test materials.

\section{Antioxidant Activity}

In order to investigate the antioxidant properties of the extracts, 2, 2-diphenyl-1-picrylhydrazyl (DPPH) assay were employed.

Scavenging effect on DPPH; $0.5 \mathrm{M}$ of the free radical source 2.2-diphenyl-1-picry hydrazyl radical (DPPH) solution in methanol was prepared and $3 \mathrm{~cm}^{3}$ of this solution was mixed with $2 \mathrm{~cm}^{3}$ of the extract solution at varying concentration $\left(1.0 \mathrm{mg} / \mathrm{ml}, 0.5 \mathrm{mg} / \mathrm{ml}\right.$. and $0.25 \mathrm{mg} / \mathrm{cm}^{3}$ ) (Cow-chin et al, 1994, Mellors and Tappel, 1996, and Lugasi et al, 1999) The decrease in absorption at $517 \mathrm{~nm}$ of DPPH was measured after 10 minutes of incubation. The actual decrease in absorption was measured against that of control and the percentage inhibition was calculated. The same experiment was carried out using Butyrate Hydroxyl Anisole (BHA), Vitamin $\mathrm{C}$ and a-Tocopherol, a known antioxidant which were all used as the standard. All tests and analysis was carried out in triplicates and the results obtained were averaged. The activity was determined as a function of their \% inhibition which was calculated using the formula;

$\%$ RSA or $\%$ inhibition $=\left\{\left(\mathrm{A}_{\mathrm{DP}} \mathrm{p}_{\mathrm{H}}-\mathrm{A}_{\mathrm{S}}\right) / \mathrm{ADPPH}\right\} \times 100$

Where As =Absorbance of the solution ADPPH = Absorbance of the DPPH solution (Hatano et al, 1988).

\section{Antimicrobial Assay}

The antimicrobial assay of each extracts was evaluated using method described by Egwaikhide et al., 2008 and Okeniyi et al., 2000.

Table 1. Result of Phytochemical screening of Stem and Leaves of Euphorbia heterophylla

\begin{tabular}{|l|c|c|}
\hline $2^{\circ}$ metabolites & Crude extract of stem & Crude extract of leaves \\
\hline Alkaloids & - & - \\
\hline Carbohydrates & + & + \\
\hline Glycosides & + & + \\
\hline Free anthraquinone & - & - \\
\hline
\end{tabular}




\begin{tabular}{|l|c|c|}
\hline Combined anthraquinone & - & - \\
\hline Reducing sugar & + & + \\
\hline Saponins & + & + \\
\hline Tannins & + & + \\
\hline Cardiac glycosides & + & + \\
\hline Steroids & + & + \\
\hline Triterpenes & + & + \\
\hline Flavonoids & + & + \\
\hline Phlobatannins & + & + \\
\hline
\end{tabular}

Where: $\quad+=$ present $\quad-=$ negative

Table 2. Result of Brine -shrimp lethality test of Euphorbia heterophylla stem and leave Extracts.

\begin{tabular}{|l|l|l|}
\hline Sample & Plant part & $\mathrm{LC}_{50} \mu \mathrm{g} / \mathrm{cm}^{3}$ \\
\hline n-Hexane fraction & Stem & 159 \\
\hline n-Hexane fraction & Leaves & 165 \\
\hline Ethyl Acetate fraction & Stem & 25 \\
\hline Ethyl Acetate fraction & Leaves & 30 \\
\hline Butanol fraction & Leaves & 21 \\
\hline Butanol fraction & Stem & 23 \\
\hline Aqueous fraction & Stem & 247 \\
\hline Aqueous fraction & Leaves & 280 \\
\hline
\end{tabular}

Table 3. \% Inhibition of DPPH -Free -Radical Scavenging Activity of Stem and Leave Extracts

\begin{tabular}{|l|l|l|l|l|l|l|l|l|l|}
\hline $\begin{array}{l}\text { Conc. } \\
\mathrm{mg} / \mathrm{cm}^{3}\end{array}$ & $\begin{array}{l}\text { Ethyl } \\
\text { hexane } \\
\text { stem \% }\end{array}$ & $\begin{array}{l}\text { Butanol } \\
\text { stem } \%\end{array}$ & $\begin{array}{l}\text { Hexane } \\
\text { stem } \%\end{array}$ & $\begin{array}{l}\text { Ethyl } \\
\text { leave } \\
\text { acetate } \\
\text { leave\% }\end{array}$ & $\begin{array}{l}\text { Butanol } \\
\text { leave \% }\end{array}$ & AA \% & BHA \% & $\alpha$-Tocopherol \% \\
\hline 0.25 & 65 & 73 & 79 & 55 & 80 & 45 & 44 & 91 & 10 \\
\hline 0.5 & 84 & 78 & 81 & 65 & 94 & 65 & 65 & 93 & 12 \\
\hline 1.0 & 90 & 83 & 88 & 89 & 98 & 94 & 68 & 94 & 12 \\
\hline
\end{tabular}

KEY: BHA = Butylated Hydroxyl Anisole. AA= Ascorbic Acid 


\section{Macrothink}

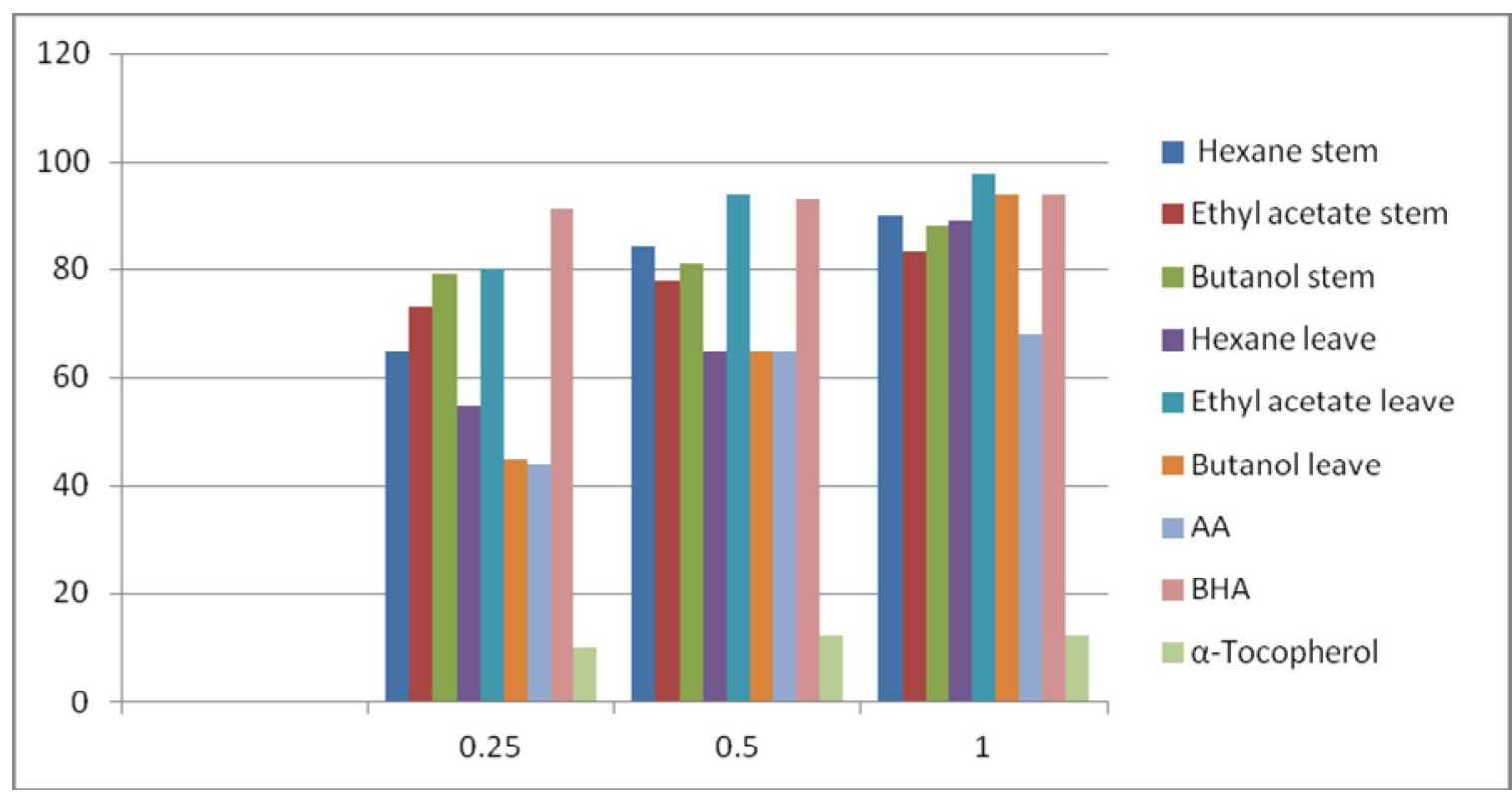

Figure 1. percent inhibition scavenging activity of DPPH of the stem and Leave extracts of Euphorbia heterophylla

Table 4. Result of Antimicrobial test of Euphorbia heterophylla stem and leave Extracts

\begin{tabular}{|c|c|c|c|c|c|c|c|}
\hline Plant part & Extracts & Concentration $\left(\mathrm{mg} / \mathrm{cm}^{3}\right)$ & S.a & E.coli & P.sa & Strep & C.a \\
\hline \multirow[t]{12}{*}{ Stem } & Hexane & 0.25 & 11 & 16 & 11 & 10 & 13 \\
\hline & & 0.5 & 14 & 20 & 14 & 16 & 15 \\
\hline & & 1.0 & 16 & 25 & 18 & 24 & 19 \\
\hline & & Control & NI & NI & NI & NI & NI \\
\hline & Ethyl acetate & 0.25 & 15 & 16 & 14 & 13 & 14 \\
\hline & & 0.5 & 24 & 23 & 21 & 18 & 19 \\
\hline & & 1.0 & 30 & 29 & 30 & 24 & 28 \\
\hline & & Control & NI & NI & $\mathrm{NI}$ & NI & NI \\
\hline & Butanol & 0.25 & 15 & 12 & 10 & 16 & 15 \\
\hline & & 0.5 & 17 & 21 & 20 & 21 & 22 \\
\hline & & 1.0 & 27 & 31 & 28 & 25 & 31 \\
\hline & & Control & NI & NI & NI & NI & NI \\
\hline \multirow{12}{*}{ Leave } & Hexane & 0.25 & 8 & 9 & 11 & 10 & 10 \\
\hline & & 0.5 & 11 & 12 & 14 & 16 & 14 \\
\hline & & 1.0 & 14 & 18 & 18 & 19 & 17 \\
\hline & & Control & NI & NI & NI & NI & NI \\
\hline & Ethyl acetate & 0.25 & 17 & 18 & 15 & 14 & 13 \\
\hline & & 0.5 & 23 & 26 & 23 & 23 & 19 \\
\hline & & 1.0 & 27 & 30 & 31 & 25 & 27 \\
\hline & & Control & $\mathrm{NI}$ & NI & $\mathrm{NI}$ & NI & NI \\
\hline & Butanol & 0.25 & 16 & 14 & 10 & 16 & 15 \\
\hline & & 0.5 & 19 & 20 & 20 & 21 & 22 \\
\hline & & 1.0 & 26 & 32 & 27 & 24 & 31 \\
\hline & & Control & NI & NI & NI & NI & NI \\
\hline
\end{tabular}

KEY: S.a=staphylococcus aureus, E.coli=Escherichia coli, Ps.a=pseudomonas aeruginosa, strep=streptococcus pneumonia, and C.a=Candida albicana 


\section{Result and Discussion}

The result of phytochemical screen presented in Table 1 showed the presence of saponinns, reducing sugar, Glycosides, Triterpenes, flavonoids, Cardiac Glycoside, Carbohydrate, steroids, tannins and phlobatannins.in the stem and leave of Euphorbia heterophlla with exception of alkaloids and anthraquinone in both sample. The presence of this phytocompounds in the methanol extract have been reported to be responsible for the anti inflammatory and anti microbial properties displayed by many medicinal plants (Taylor et al,1996) Falodun et al 2006 : Salihu and Garba, 2008. The result of brine shrimp lethality test (BST) (Table 2) are in agreement with those of phytochemical where the majority of the phytocompound appeared to be present in the crude extract of the plant ( Table $1 \& 2$ ). The activities exhibit by crude extracts of stem and leave from highly polar solvent extracts to non-polar solvent extracts ( Butanol, Ethyl acetate and n-Hexane ). The highest, stem extract ( Butanol) and leave (Butanol) (BST $\mathrm{LC}_{50} 21 \mu \mathrm{g} / \mathrm{cm}^{3}$ and $23 \mu \mathrm{g} / \mathrm{cm}^{3}$ ) to the lowest stem ( n-Hexane) and leave (n-Hexane) (BST LC $50159 \mu \mathrm{g} / \mathrm{cm}^{3}$ and $164 \mu \mathrm{g} / \mathrm{cm}^{3}$ ) respectively. However the aqueous extracts of stem and leave (BST LC Lo $_{50} 1000 \mu \mathrm{g} / \mathrm{cm}^{3}$ ) was in active. In this anti microbial assay, zone diameter of inhibition of $21-25 \mathrm{~mm}$ and $26-35 \mathrm{~mm}$ correspond to moderate and maximum activities respectively (Aminabhavi et al., 1984). The result obtained (Table 4) show that most of the extract indicated high presence of phytocompound as well as high activities against the shrimp larvae also showed high activities against the test organisms. For instance stem extract( Butanol) and leave (Butanol) (BST LC ${ }_{50} 21 \mu \mathrm{g} / \mathrm{cm}^{3}$ and $23 \mu \mathrm{g} / \mathrm{cm}^{3}$ ) showed high activity against all the test microbes with maximum zone inhibition diameter of $31 \& 32 \mathrm{~mm}$ against E.coli, and C. albicans ( see Table 4). Similarly stem extract ( Ethyl acetate ) and leave extract (ethyl acetate 1) (BST LC L $_{0} 25 \mu \mathrm{g} / \mathrm{cm}^{3} \& 30 \mu \mathrm{g} / \mathrm{cm}^{3}$ ) inhibited the growth of all the test microbes, ( except. Streptomycin) with maximum inhibition diameter of $30 \& 31 \mathrm{~mm}$ against Pseudomonas aeruginosa. However, low activities were generally recorded in the n-hexane extracts which is conformity with low activity in BST (see Table 2-3). stem extract (n- Hexane) (BST LC L $_{50} 159 \mu \mathrm{g} / \mathrm{cm}^{3}$ ) and leave extract (n-Hexane) $\left(164 \mu \mathrm{g} / \mathrm{cm}^{3}\right)$ exhibited low activities against all test microbes(Table 3).The moderate anti microbial activities recorded in different solvent extracts of stem and leave of $E$. heterophlla against E.coli, Candida albican, Streptomycin, staphylococcus aureus and Pseudomonas aeruinosa suggest that this plant s may be potential source of ingredients that may be employed in the treatment of typhoid, malaria, boil, respiratory tract and other diseases cause by the test organisms. Antioxidant activity of all extracts as measured by ability to scavenge (DPPH) free radicals was compared with the standard s Ascorbic acids, Butylated Hydroxyl Anisole (BHA) and $\alpha$ - Tocopherol. It was observed that Ethyl acetate of leave extracts had higher activity than the n-Hexane and Butanol extracts of the leave. At concentration of $1.0 \mathrm{mg} / \mathrm{cm}^{3}$.The scavenging activity of ethyl acetate extract reached $97 \%$. n-Hexane and Butatnol reached $89 \%$ and $93 \%$ respectively. The DPPH radicals scavenging ability of all the extracts were closer to that of BHA and higher than Ascorbic acid and $\alpha$-Tocopherol(see fig 1). The ethyl acetate of both stem and leave scavenging ability was found to be higher than BHA $94 \%$ at $1.0 \mathrm{mg} / \mathrm{cm}^{3}$ the study show that the extracts have the proton donating ability and could serve as free -radical inhibitor s.. 


\section{Conclusion}

The maximum antimicrobial activities exhibited by the ethyl acetate and Butanol extract of stem and Leave of E. heteophylla against E. coli, and Candida albicans respectively suggest that their extracts may be used for the treatment of typhoid, malaria, boil, respiratory tract and other diseases cause by the test organisms. The higher antioxidant activities exhibited by the extracts indicate that the extracts have the proton donating ability and could serve as free -radical inhibitor. This shows that the plant could be useful as antitumor, anticancer and as antimicrobial agent.

\section{Nowledgement}

The Authors are grateful to M.O Akpai of Department of Biological science Kaduna, and Dr. M.S Abubakar of Department of Pharmachognosy Ahmadu Bello University Zaria for their contributions.

\section{References}

Aminabhavi, T. M., Biradar, N. S., Divakar, M. C., \& Rudzinski, W. E. (1984). Biologically Active Bimetallic Complexes Formed from Acetylacetonate of copper, colbalt and Nickel. inorganic chimica Acta, 92, 99-105.

Egwaikhide, P. A, Okeniyi S. O., \& Gimba, C. E., (2008). Screening for Antibacterial Activity and Phytochemial Constituent $\mathrm{s}$ of some Nigerian Medicinal Plant s. Advances Biological Research, 1(5-6),155-158.

Fatope, M. O., Ibrahim, H., \& Takeda, Y. (1993). Screening of higher plants requested as pesticides using the brine Shrimp lethality assay. International Journal of Pharmacognosy, 37 (4), 230-254.

Falodun, A., \& Agbakwuru, E. O. P, (2004). Phytochemical analysis and Laxatative activity of Euphorbia Heyerophylla linn (Euphorbiaceae). Park. Journal of sci.Research, 47(5), 454-459.

Falodun A, Agbakwuru, E. O. P., \& Ukoh, G. C, (2003). Antibacterial Activity of Euphorbia heterophylla Linn(family Euphorbiaceae). Park. Journal of sci. Research (6), 471-472.

Garba, S., \& Salihu, L. (2009). Aphyosemion Gardneri Test (AGT)for Cytotoxicity. Nig.Journal of Scientific Research, 2(3),56-57.

Gulcin, I., M. Oktay, O.. kufrevioeglu, I., \& Aslan, A. (2002). Determination of antioxidant activity of Linchen certraria islandica (L.). Ach.J. Ethnopharmacol, 79, 325-329. http://dx.doi.org/10.1016/S0378-8741(01)00396-8

Hatano, T., Kagawa, H., Yasuhora, T., \& Okuta, T. (1988). Two new Flavonoids and other constituents in licorice root: Their relative astringency and radical scavenging effects Chemical and Pharmaceutical Bulletin, 36, 2090-2091. http://dx.doi.org/10.1248/cpb.36.2090

Hartwell, I., Andrew, B., \& Mine, .R, (1969). Euphorbia genucilata Quisumbing and 
Hyperricifolia Linn: The useful plant of West Africa. Biochemical Journal, 2(1), 69-70.

Lugasi, A., Honvahrich, P., \& Dworshark, A. (1999). Addition information to the in-vitro, Antioxidant Activity of Ginkgo Biloba L. Phototherapy Research, 13(3), 160-162. http://dx.doi.org/10.1002/(SICI)1099-1573(199903)13:2<160::AID-PTR402>3.0.CO;2-H

Mellor's, H., \& Tappel, A. L. (1996). The inhibition of mitochondrial per oxidation by ubiquinone and ubiquinol. Journal of Biology and chemistry, 241(6), 4353-4356.

Oloyede, G. K. Akpomedeye, P. O., Soyinka, J., Oguntokun, O., \& Emmanuel, T. (2010). Phytochemical screening, Antimicrobial and Antioxidant Activities of four Nigerian Medicinal plants. Scholars Research Library, Annual of Biological Research, 1(2), 114-120.

Oloyede, G. K., Oke, M. J., Raji Y., \& Olugbode, A. T. (2010). Antioxidant and Anti convulsant Alkaloids in Crinum Ornatum Bulb Extract. World Journal of Chemistry, 2(5), 26-31.

Omale, J., \& Emmanuel, T. F. (2010). Phytochemical Composition, Bioactivity and Wound Healing Potential of Euphorbia Heterophylla (Euphorbiaceae) Leaf Extract. International Journal on Pharmaceutical and Biomedical Research, 1(2), 54-63.

Okeniyi, S. O, ObafemI, C. A., Bamgbose, J. T., Egwaikhide P. A., \& Akporhorhonor. E. E. (2007). Analgesic Activity of Azadirachta indica (Neem) leaves Extract and honey combination in mice. Chem, Tech Journal, 3(2), 538-544.

Sofowora, A. (2008). Medicinal plants of Traditional Medicine in Africa. $3^{\text {rd }}$ Edition, Spectrum Books, Ibadan, Nigeria. 199- 181.

\section{Copyright Disclaimer}

Copyright reserved by the author(s).

This article is an open-access article distributed under the terms and conditions of the Creative Commons Attribution license (http://creativecommons.org/licenses/by/3.0/). 